\title{
Relationship between the Management Accounting Information Usage, Market Orientation and Performance: Evidence from Vietnamese Tourism Firms
}

\author{
Trang Huyen DO'1, Huyen Mong LE², Diem Thuy Thi LUONG ${ }^{3}$, Quanh Thi TRAN ${ }^{4}$
}

Received: August 01, 2020 Revised: September 06, 2020 Accepted: September 10, 2020

\begin{abstract}
The study investigates the relationship between broad-scope management accounting information usage, market orientation, and the firm performance. This study employs a survey data of 149 top-level and mid-level managers working in Vietnamese tourism enterprises. To analyze research data, we employ SmartPLS 3 software. The analytical process include measurement model evaluation (evaluate the scale's validity and reliability) and structural model evaluation (test research hypotheses). The results reveal that broad-scope management accounting information usage has a positive direct effect on market orientation dimensions (include information generation, information dissemination, and responsiveness). Then, market orientation dimensions also have positive direct effects on the performance of Vietnamese tourism firms, excluding information dissemination. Moreover, this study also reveals that the market orientation dimensions mediate the relationship between broad-scope management accounting information usage and firm performance. The findings of this study suggest that tourism firms should pay more attention to the use of management accounting information in decision-making. With the increasingly fierce competition of the tourism firms today, capturing and meeting the needs of the market is a prerequisite to help firms enhance their competitiveness and improve their performance. To do that, Vietnamese tourism firms need to consider pursuing market orientation and enhancing broad-scope management accounting information usage.
\end{abstract}

Keywords: Broad-Scope Management Accounting Information Usage, Firm Performance, Market Orientation, Tourism Firms

JEL Classification Code: M14, D22, C31

\section{Introduction}

The tourism industry continues to be seen by many international agencies and governments of the developing countries as an important sector which contributes to the

${ }^{1}$ First Author. Vice Dean, Faculty of Economics \& Accounting, Quy Nhon University, Vietnam. Email: dohuyentrang@qnu.edu.vn

${ }^{2}$ Corresponding Author. PhD Student, School of Accounting, University of Economics Ho Chi Minh City, Nguyen Dinh Chieu, Ho Chi Minh City, Vietnam [Postal Address: 170 An Duong Vuong Street, Quy Nhon City, Binh Dinh Province, 55000, Vietnam]

Email: lemonghuyen@qnu.edu.vn

${ }^{3}$ Lecturer, Faculty of Economics \& Accounting, Quy Nhon University, Vietnam. Email: luongthithuydiem@qnu.edu.vn

${ }^{4}$ Lecturer, Faculty of Economics \& Accounting, Quy Nhon University, Vietnam. Email: tranthiquanh@qnu.edu.vn

(c) Copyright: The Author(s)

This is an Open Access article distributed under the terms of the Creative Commons Attribution Non-Commercial License (https://creativecommons.org/licenses/by-nc/4.0/) which permits unrestricted non-commercial use, distribution, and reproduction in any medium, provided the original work is properly cited.
GDP, employment, and government revenues (Hampton, Jeyacheya, \& Long, 2018). Tourism is considered as one of the fastest growing industries (Shahzad, Shahbaz, Ferrer, \& Kumar, 2017), that can facilitate economic recovery and growth if the potential of this industry is managed in a proper manner. Additionally, tourism is one of the largest and most dynamic sectors that have significant effects on earnings, employment, foreign exchange, and economic growth. It is recognized as a major contributor to the economic growth and development in an emerging market (Shahzad et al., 2017). In recent years, the position of Vietnam tourism has improved significantly on the world tourism map when it became an attractive destination for domestic and international tourists. Tourism has become a strategic industry in Vietnam and in 2019 it contributed around 6.6 percent in total of GDP (WTTC, 2020) becoming the 'centerpiece' (Gillen, 2014) of the Vietnamese economy. However, despite its remarkable achievements, it is said that the development of Vietnam's tourism does not commensurate with its potential. The 
tourism industry still has many limitations in terms of policies, infrastructure or human resources, etc. These restrictions create barriers to attracting tourists to Vietnam. It also reduces the competitive strength and performance of Vietnamese tourism businesses. Therefore, in order to maintain old customers, attract more new customers and improve firm performance, it is necessary for Vietnamese tourism businesses to use management accounting information effectively, pursuing market orientation to create more superior values for customers as well as a more competitive advantage for businesses.

Market orientation literature has two main contents. The first is to clarify the concept of market orientation and the second is to examine the impact of market orientation on firm performance. For the first content, the researchers focused on clarifying the concept and measure of the term "market orientation". Accordingly, there have been two approaches to the concept of market orientation. These are cultural approaches (Deshpande \& Webster, 1989; Narver \& Slater, 1990) and behavioral approach (Hunt \& Morgan, 1995; Jaworski \& Kohli, 1993; Kohli \& Jaworski, 1990). For the second content, market orientation is found to play a key role in organizational performance-based studies (Jaworski \& Kohli, 1993; Matsuno \& Mentzer, 2000; Narver \& Slater, 1990). The majority of authors have studied the effect of market orientation on firm performance. In particular, in addition to the differences between the two approaches to market orientation, these studies also have differences in the measurement of firm performance. Specifically, Narver and Slater (1990); Zhou \& cộng sự (2008) measured firm performance by return on assets (ROA). Meanwhile, Baker and Sinkula (1999) measure performance with more diverse and mixed measures including changes in relative market share, the success of new products, and overall performance. Wang, Chen, and Chen (2012) measured performance with both the financial scale and a customer-based scale. In addition, there are few studies that investigated the effect of market orientation on micro-level performance in organizations (i.e. brand performance) such as O'Cass and Ngo (2007). Although market orientation companies are expected to be better at reacting to formal and informal feedback received from customers, channels, and competitors (Baker \& Sinkula, 1999) and there is also evidence to support the positive effect of market orientation on firm performance (Jaworski \& Kohli, 1993; Narver \& Slater, 1990; Slater \& Narver, 1994), there is still a lot of debate among researchers about how market orientation affects firm performance. Therefore, it becomes necessary to continue to research about the relationship between market orientation and firm performance.

Chenhall and Morris (1986) first formalized the four key characteristics of management accounting information. They developed and tested a useful cognitive measurement tool on management accounting information in four dimensions broad-scope, timeliness, aggregation, and integration. Almost all later studies on management accounting information inherited a scale by Chenhall and Morris (1986), however, most studies focus on broad-scope because of its important role in supporting managers to implement planning, control and decision-making (Cadez \& Guilding, 2008; Chong, 1996; Chong \& Chong, 1997; Gul \& Chia, 1994; Mia \& Chenhall, 1994; Mia \& Clarke, 1999; Naranjo-Gil \& Hartmann, 2007; Nguyen, 2018). Empirical evidence from prior studies shows that broad-scope management accounting information plays an important role in implementing strategy, improving competitive advantage, and enhancing the firm performance (Ha, 2020; Mia \& Clarke, 1999; Nguyen, Mia, Winata, \& Chong, 2017; Phornlaphatrachakorn \& Na-Kalasindhu, 2020). Therefore, management accounting information can contribute to promoting market orientation, thereby improving firm performance. However, there is very little research on the use of management accounting information in market-orientation tourism firms. This is a research gap that this article will attempt to fill it.

In summary, this study's objective is to test the relationship between broad-scope management accounting information usage, market orientation, and firm performance in Vietnamese tourism firms. The findings will provide empirical evidence on the role of broad-scope management accounting information in promoting market orientation. Then, the market-oriented activities are implemented effectively will contribute to improving firm performance of Vietnam tourism.

The remainder of this paper is structured as follows: Section 2 presents a literature review and hypotheses. Section 3 presents samples, data collection, and variable measurement. Next, research results and discussion are presented in section 4 . Finally, section 5 presents conclusions, research limitations, and future research directions.

\section{Literature Review and Hypotheses}

\subsection{Market Orientation}

Originating from the marketing concept, market orientation has become a cornerstone of marketing theory, growing rapidly in recent years in two dominant streams regarding its nature (O'Cass \& Ngo, 2007). The synthesis of several previous theories show that there are two different views of the concept of market orientation: cultural approach and behavioral approach. The cultural approach defines market orientation is an aspect of an organization's culture, putting the highest priority on creating and maintaining superior value for customers (Deshpande \& Webster, 1989; 
Narver \& Slater, 1990). In this view, market orientation consists of three components: customer orientation, competitor orientation, and inter-functional coordination. Meanwhile, the behavioral approach defines market orientation as the generation of market intelligence at an organizational level relevant to current and future customer needs, dissemination of the intelligence across departments and organization - wide responsiveness to it (Hunt \& Morgan, 1995; Jaworski \& Kohli, 1993; Kohli \& Jaworski, 1990). Corresponding to this view, market orientation consists of three components: intelligence generation, intelligence dissemination, and responsiveness.

Thus, according to the first approach, market orientation is considered as an aspect of organizational culture, created and maintained to provide specific rules for behavior within organizations. Meanwhile, the second approach shows that market orientation is a set of behaviors, providing managers with a practical guide to doing business. Both of these approaches are influential and dominant in empirical research on market orientation as well as create a lot of controversy about the nature of market orientation. In this paper, we study and measure market orientation according to the second approach.

\subsection{Broad-Scope Management Accounting Information Usage and Market Orientation}

The market-oriented philosophy states that the planning and coordination of all company activities focus on the key goal of satisfying customer needs (Jaworski \& Kohli, 1993). Narver and Slater (1990) conclude that customer orientation is one of the three important conceptual components of market orientation and are considered by Jaworski and Kohli (1993) as a central component of market orientation. To satisfy customer needs, companies must constantly strive to retain old customers and attract new ones (Kaplan \& Atkinson, 1998; Kaplan \& Norton, 1996). Customer-focused ideology is embedded in many management philosophies, i.e. in total quality management, just-in-time, or flexible manufacturing. There are several general reasons why customer satisfaction should lead to better performance. High customer satisfaction should indicate increased loyalty for current customers, reduced price elasticity, insulation of current customers from competitive efforts, lower costs of future transactions, reduced failure costs, lower costs of attracting new customers, and an enhanced reputation for the firm (Hyvönen, 2007). In order to attract new customers while retaining old customers, companies understand customers' shopping behavior, the quality of products/services of firm and competitors, technology development trends as well as information on competitors' responses, etc. (Guilding \& McManus, 2002; Hyvönen, 2007; Kaplan \& Atkinson, 1998; Kaplan \& Norton,
1996). Tourism firms needs to understand the tastes, and behaviors of their customers and it is especially important to be able to provide services that satisfy their customers' satisfaction. In order to do so, the tourism firms needs to have an accounting information system that provides broad-scope information (Bouwens \& Abernethy, 2000; Hyvönen, 2007) because a broad-scope management accounting system not only provides both financial and non-financial information, both internal and external information, both past and future direction information (Chenhall \& Morris, 1986; Soobaroyen \& Poorundersing, 2008). The broad-scope management accounting system very well supports tourism industry in information generation, information dissemination, and responsiveness. Therefore, we propose the hypothesis as follows:

H1a: There is a direct positive relationship between broad-scope management accounting information usage and information generation.

H1b: There is a direct positive relationship between broad-scope management accounting information usage and information dissemination.

H1c: There is a direct positive relationship between broad-scope management accounting information usage and responsiveness.

\subsection{Market Orientation and Firm Performance}

Many years before the 1990s, when there was no valid measurement of market orientation and no systematic analysis of its effects on firm performance, it was widely believed that an organization which increases its market orientation will improve its performance (Narver \& Slater, 1990). Later, when there were valid measures for the concept of market orientation, researchers presented concrete evidence supporting the positive effect of market orientation on a certain aspect of firm performance (Jaworski \& Kohli, 1993; Narver \& Slater, 1990). Specifically, to maximize the long-term performance, businesses know that they must build and maintain a long-term, mutually beneficial relationship with the buyers. Market orientation, meanwhile, is the organizational culture that most effectively creates the necessary behaviors to create superior value for buyers and, thus, continuously enhances superior performance (Narver \& Slater, 1990). Kohli and Jaworski (1990) argued that market orientation provides a unified focus for the efforts and projects of individuals and departments within the organization, thus bringing superior performance. More recently, empirical evidence also indicates that market orientation enhances organizational performance (Buli, 2017; Charles, Joel, \& Samwel, 2012; Gruber-Muecke \& Hofer, 2015; Zhou, Li, Zhou, \& Su, 2008). 
As mentioned above, the market orientation include information generation, information dissemination, and responsiveness. Information generation is the beginning of market orientation (Kohli \& Jaworski, 1990; O’Cass \& Ngo, 2007). It is necessary for a tourist firm to manage all the information related to the current and future needs of a customer as well as the exogenous factors affecting that need. This enable firms to meet customer needs, create competitive advantages, and improve firm performance (Zhou, Brown, \& Dev, 2009). However, this process requires the participation of all relevant parts of an organization (Kohli \& Jaworski, 1990; Zhou et al., 2008). Dissemination of information is crucial because it helps departments work together to achieve common goals. We, therefore, argue that information dissemination has a positive effect on firm performance. Finally, responsiveness is an action taken in response to information that has created and disseminated. A tourism firm can generate and disseminate information internally; however, very little is accomplished if the market demand is not met (Kohli \& Jaworski, 1990; Wang et al., 2012; Zhou et al., 2009). Responding to customer needs helps businesses bring value to customers and, subsequently, improve firm performance. Consequently, responsiveness has a positive impact on firm performance. Therefore, we propose the following hypothesis:

H2a: There is a direct positive relationship between information generation and firm performance.

$\boldsymbol{H} \mathbf{2 b}$ : There is a direct positive relationship between information dissemination and firm performance.

H2c: There is a direct positive relationship between responsiveness and firm performance.

\subsection{Broad-Scope Management Accounting Information Usage and Firm Performance}

The resource-based view of the firm has influenced the field of strategic management (Li \& Liu, 2014; Wu, Chen, \& Jiao, 2016). The resource-based view addresses that the accumulation of valuable, rare, inimitable, and nonsubstitutable (VRIN) resources are the basis of enterprise competitiveness and economic rent (Barney, 1991). Today, information has been recognized as one of the powerful resources that can significantly affect the wealth of businesses (Barney, 1991; Nguyen, 2018). Successful companies not only pay attention to financial performance but also pay attention to non-financial performance such as defective product ratio, delivery time, number of new products, guest satisfaction, and staff, etc. (Kaplan \& Atkinson, 1998; Kaplan \& Norton, 1996). Therefore, to deal with the changing environment, the challenge for any management accounting system is to provide broad-scope information to help managers make wise economic decisions and direct users to aim at the purpose and strive for organizational change (Baines \& Langfield-Smith, 2003; Horngren, 1995). Drawing on the resource-based view, we argue that broadscope management accounting information can contribute to improving the firm performance of Vietnamese tourism companies. Therefore, the third research hypothesis is proposed as follows: (see Figure 1).

H3: There is a direct positive relationship between broad-scope management accounting information usage and firm performance.

\section{Research method}

\subsection{Sampling and Data Collection}

The self-administered questionnaire was sent to middle and top managers who conveniently selected from the list of 2.409 firms provided by the Vietnam Tourism Association. Each enterprise, a top-level or mid-level manager (such as $\mathrm{CEO}, \mathrm{CFO}$, head of the department, and deputy of department) with a minimum of two years' experience was selected to ensure a full understanding of the company, help improve data quality. Our interviewers contacted the responders in advance by phone to attract their cooperation. We also informed them that these answers will be kept confidential, only for academic research purposes, and promise to provide them with a summary of the survey results.

The questionnaire was sent to 400 respondents who accepted the survey. After ten days, the authors sent a reminder email to those who did not respond and after two times of sending reminder email and one time of the last call, the authors obtained 157 responses (reaching 39.25\%). In 157 responses, there are 8 reviews with the same level for all statements. Therefore, all 149 responses were used to analyze the data. Table 1 presents the sample information from 149 samples (see Table 1).

\subsection{Measurement Scales}

The scale of the variables in the model is inherited from prior studies, specifically as follows: First, the scale of using broad-scope management accounting information is developed by Chenhall and Morris (1986). This scale has been subsequently used in many studies (Agbejule, 2005; Nguyen, 2018; Nguyen \& Doan, 2016; Nguyen et al., 2017; Soobaroyen \& Poorundersing, 2008). Second, to measure market orientation, we adapted to the scale of Zhou et al. (2008). This is a scale originally developed by Jaworski and Kohli (1993). Finally, five items adapted from Baines and Langfield-Smith (2003); , and used subsequently by Hoque (2011) to measure firm performance. These items were used to assess the financial firm performance of enterprises. Details of items are shown in Appendix A. 


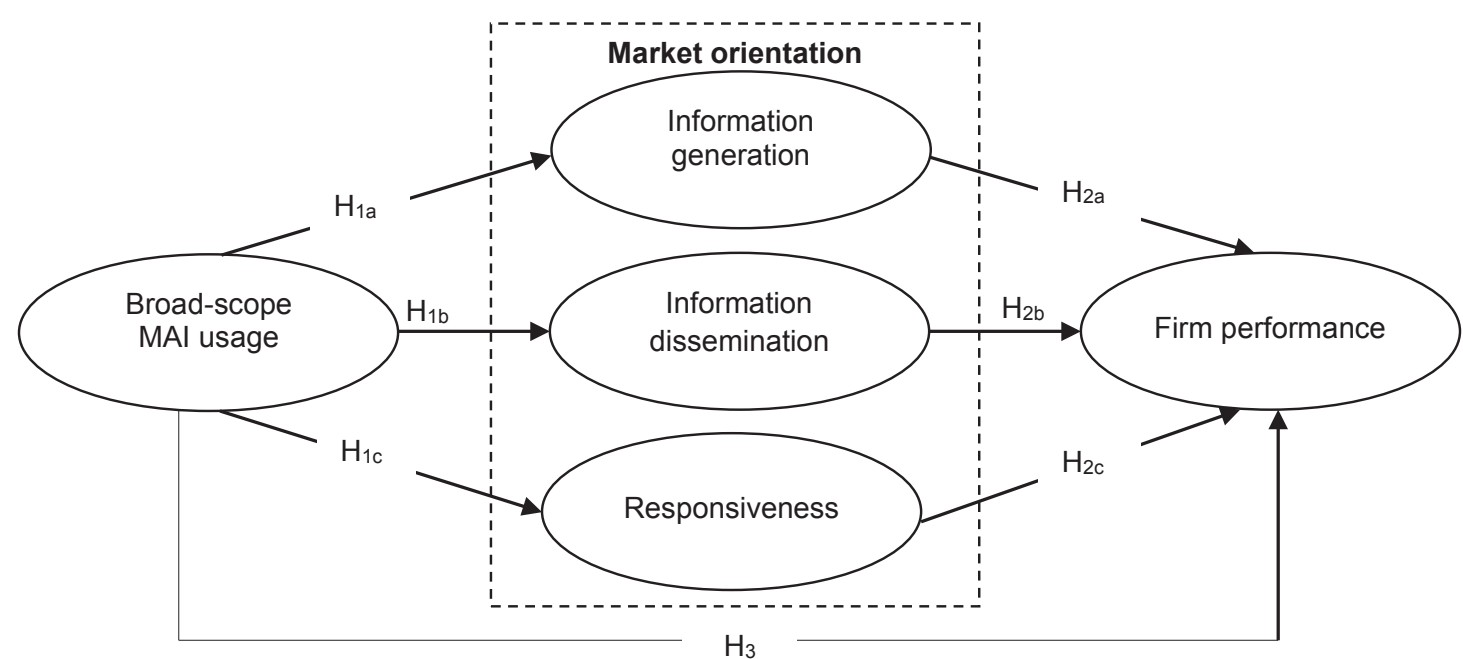

Figure 1: Research model

Table 1: Demographic data

\begin{tabular}{|l|c|c|l|c|c|}
\hline Demographics & Frequency & Percent & \multicolumn{1}{|c|}{ Demographics } & Frequency & Percent \\
\hline \multicolumn{7}{|l|}{ Type of company } & \multicolumn{1}{|l|}{ Firm age } & 64 & 42.95 \\
\hline Private company & 21 & 14.09 & $\leq 5$ years & 43 & 28.86 \\
\hline Limited company & 82 & 55.04 & $6-10$ years & 27 & 18.12 \\
\hline Join stock company & 46 & 30.87 & $11-20$ years & 12 & 8.05 \\
\hline Number of employees & 58 & 38.93 & $>50$ years & 3 & 2.01 \\
\hline$\leq 50$ peoples & 49 & 32.88 & Company's Ownership & 4 & 2.68 \\
\hline $51-100$ peoples & 26 & 17.45 & State-owned & 106 & 71.14 \\
\hline $101-200$ peoples & 14 & 9.40 & Non-State-owned & 39 & 26.17 \\
\hline $201-500$ peoples & 2 & 1.34 & Foreign direct investment &
\end{tabular}

\section{Research Results}

\subsection{Evaluating Scales Reliability and Validity}

Results of measuring scales reliability show that Cronbach's alpha (CA) and composite reliability (CR) of all constructs are greater than 0.70 (Table 2), proving that scales for latent variables have high reliability. The factor loading of all items is in the range from 0.504 to 0.873 (Appendix A), higher than the cut-off value of 0.5 (Hulland, 1999). The t-values of all items are in the range from 5.654 to 40.577 (Appendix A), satisfying the condition greater than 1.96 to have statistically significant. In addition, the variable scales also achieve convergent validity because the average variance extracted (AVE) is higher than the minimum threshold of 0.50 (ranging from 0.572 to 0.720 ) (Hair, Hult, Ringle, \& Sarstedt, 2017; Hulland, 1999) (see Table 2).
We based on the Fornell-Larcker criteria to evaluate the discriminant validity of the scale for the study constructs. The results in Table 3 show that the square root of the average variance extracted (AVE) of the constructs ranges from 0.687 to 0.849 (numbers on the diagonal) is greater than the correlation coefficient among the constructs (numbers below the diagonal). In addition, the correlation coefficients of constructs (ranging from 0.326 to 0.580 ) are smaller than the composite reliability in Table 2 (ranging from 0.814 to 0.891 ) (Fornell \& Larcker, 1981). Moreover, we also employed the Heterotrait-Montrait (HTMT) test to evaluate the discriminant validity of constructs (Henseler, Ringle, \& Sarstedt, 2015). Table 3 shows that the HTMT values (numbers in parentheses) range between 0.461 and $0.738(<0.90)$, providing clear evidence for discriminant validity. 
Table 2: Results of evaluating scales reliability

\begin{tabular}{|l|c|c|c|}
\hline Constructs & Cronbach's Alpha & Composite Reliability & $\begin{array}{c}\text { Average Variance } \\
\text { Extracted }\end{array}$ \\
\hline Management accounting information usage & 0.836 & 0.891 & 0.671 \\
\hline Information generation & 0.736 & 0.851 & 0.656 \\
\hline Information dissemination & 0.714 & 0.837 & 0.720 \\
\hline Responsiveness & 0.798 & 0.881 & 0.712 \\
\hline Firm performance & 0.717 & 0.814 & 0.572 \\
\hline
\end{tabular}

Table 3: Fornell-Larcker Criterion and Heterotrait-Monotrait Ratio (HTMT)

\begin{tabular}{|l|l|l|l|l|l|}
\hline Constructs & \multicolumn{1}{|c|}{$\mathbf{1}$} & \multicolumn{1}{|c|}{$\mathbf{2}$} & \multicolumn{1}{|c|}{$\mathbf{4}$} & $\mathbf{5}$ \\
\hline 1. Management accounting information usage & 0.819 & & & & \\
\hline 2. Information generation & $\begin{array}{l}0.580 \\
(0.738)\end{array}$ & 0.810 & & & \\
\hline 3. Information dissemination & $\begin{array}{l}0.404 \\
(0.553)\end{array}$ & $\begin{array}{l}0.399 \\
(0.588)\end{array}$ & 0.849 & & \\
\hline 4. Responsiveness & $\begin{array}{l}0.480 \\
(0.582)\end{array}$ & $\begin{array}{l}0.531 \\
(0.699)\end{array}$ & $\begin{array}{l}0.326 \\
(0.461)\end{array}$ & 0.844 & \\
\hline 5. Firm performance & $\begin{array}{l}0.496 \\
(0.637)\end{array}$ & $\begin{array}{l}0.509 \\
(0.684)\end{array}$ & $\begin{array}{l}0.395 \\
(0.585)\end{array}$ & $\begin{array}{l}0.515 \\
(0.654)\end{array}$ & 0.687 \\
\hline
\end{tabular}

Note: Numbers on the diagonal (bold) is the square root of average variance extracted (AVE); numbers below the diagonal is correlation between variables according to Fornell \& Lacker (1981); The numbers in parentheses is HTMT.

\subsection{Testing the Hypotheses}

In this study, we use SmartPLS3 software to analyze data. The analysis results show that the $\mathrm{R}^{2}$ of the dependent variables are greater than 0.1 (specifically, $\mathrm{R}^{2}$

$=0.336, \mathrm{R}_{\text {Information dissemination }}^{2}=0.163, \mathrm{R}_{\text {Responsiveness }}^{2}=0.230$, $\mathrm{R}_{\text {Fim performance }}^{2}=0.393$ ), demonstrating that the research model is consistent with the data collected.

Firstly, the test results show that the use of broadscope management accounting information has a positive effect on information generation $(\beta=0.580$; $\mathrm{p}<0.01$; $\mathrm{t}=10.268)$, Information dissemination $(\beta=0.404 ; \mathrm{p}<0.01$; $\mathrm{t}=6.310)$, and responsiveness $(\beta=0.480 ; \mathrm{p}<0.01$; $\mathrm{t}=7.926$ ), Therefore, H1a, H1b, and H1c are supported.

Secondly, the result shows that information generation has a positive effect on firm performance $(\beta=0.193$; $\mathrm{p}<0.05 ; \mathrm{t}=2.014)$, proving $\mathrm{H} 2 \mathrm{a}$ is supported. The hypothesis $\mathrm{H} 2 \mathrm{c}$ is also supported with $(\beta=0.270 ; \mathrm{p}<0.01$; $\mathrm{t}=3.505)$, implying that the responsiveness has a positive effect on firm performance. In contrast, hypothesis $\mathrm{H} 2 \mathrm{~b}$ is not supported $(\beta=0.152 ; \mathrm{p}>0.05 ; \mathrm{t}=1.615)$, so there is not enough evidence to prove that information dissemination affect firm performance.

Finally, hypothesis $\mathrm{H} 3$ is not supported because the results show that the use of management accounting information do not affect firm performance $(\beta=0.192$; $p>0.05 ; t=1.541)$. However, we find that the indirect effect of broad-scope management accounting information usage on firm performance through market-orientation dimensions (information generation, Information dissemination and responsiveness $)$ is significant $(\beta=0.303 ; \mathrm{p}<0.01 ; \mathrm{t}=3.693)$ (see Table 4).

\section{Discussion and Conclusions}

The findings reveal that there is a relationship between broad-scope management accounting information usage, market orientation dimensions (information generation, Information dissemination, and responsiveness), and firm performance of tourism businesses in Vietnam. Specifically, using broad-scope management accounting information will promote effective market-orientated activities, thereby improving the firm performance of tourism companies. In addition, the use of broad-scope management accounting information also has a positive impact on the performance of Vietnamese tourism businesses. Although the use of management accounting information does not directly affect firm performance, it has an indirect effect on firm performance via market orientation. 
Table 4: Results of hypothesis testing

\begin{tabular}{|c|c|c|c|c|}
\hline Hypotheses & $\beta$ & $\mathrm{p}$-value & t-value & Conclusions \\
\hline \multicolumn{5}{|l|}{ Indirect effects } \\
\hline H1a: MAI usage $\rightarrow$ Information generation & $0.580^{4 * *}$ & 0.000 & 10.268 & Supported \\
\hline H1a: MAI usage $\rightarrow$ Information dissemination & $0.404^{*+*+}$ & 0.000 & 6.310 & Supported \\
\hline H1a: MAl usage $\rightarrow$ Responsiveness & $0.480^{* * *+}$ & 0.000 & 7.926 & Supported \\
\hline H2a: Information generation $\rightarrow$ Firm performance & $0.193^{* *}$ & 0.045 & 2.014 & Supported \\
\hline H2b: Information dissemination $\rightarrow$ Firm performance & $0.152^{\mathrm{ns}}$ & 0.107 & 1.615 & Not supported \\
\hline H2c: Responsiveness $\rightarrow$ Firm performance & $0.270^{* * *+}$ & 0.000 & 3.505 & Supported \\
\hline H3: MAl usage $\rightarrow$ Firm performance & $0.192^{\text {ns }}$ & 0.124 & 1.541 & Not supported \\
\hline \multicolumn{5}{|l|}{ Indirect effects } \\
\hline MAI usage $\rightarrow$ Firm performance & $0.303^{*+*+}$ & 0.000 & 3.693 & Supported \\
\hline
\end{tabular}

Note: ${ }^{* * *}$ : Correlation is significant at the $1 \%$ level (2 - tailed t-test); ${ }^{* * *}$ : Correlation is significant at the $5 \%$ level (2 - tailed t-test); ns:

Correlation is not significant at the $5 \%$ level (2 - tailed t-test).

With the above research results, our research has shown the important role of broad-scope management accounting information, according to broad-scope management accounting information is a piece of useful information helping market-oriented tourism firms successfully implement their business strategies. This research result is consistent with previous studies (Henri, 2006; Yuliansyah, Khan, \& Fadhilah, 2019) that reveal management accounting information has a positive effect on market orientation. Therefore, managers of Vietnamese tourism enterprises need to invest in perfecting the management accounting system and increasing the use of broad-scope management accounting information in decision-making (Nguyen \& Le, 2020; Pham, Dao, \& Bui, 2020).

Moreover, our research results also show the positive impact of market orientation on the firm performance of Vietnamese tourism enterprises. Moreover, the study results also finds a significant mediating effect of market orientation on the relationship between using management accounting information and firm performance. The results of this research contribute to the evolved market-oriented research field. The findings reveal that Vietnamese tourism companies (in an emerging economy) should also strengthen market-oriented behaviors to better understand and satisfy the needs of domestic and foreign tourists (Zhou et al., 2009; Zhou et al., 2008). In particular, firms should develop their management accounting system to create complete information about market changes, needs, and tastes of travelers, competitors' actions, etc. In addition, firms must also create a mechanism to disseminate inside information quickly and effectively in order to respond flexibly to market changes, customers, and competitors (Guilding \& McManus, 2002; Nguyen, 2018).
This study has still some limitations. Firstly, our sample size is quite small and we selected a convenient method so further studies should expand the sample size. Secondly, this study used cross-sectional data that has a limit in concluding a causal relationship between using broad-scope management accounting information, market orientation, and firm performance (Luft \& Shields, 2003). Subsequent researches may be overcome by surveying two times. Next, this study only covers one dimension of management accounting information that is broadscope, future studies may be cover all four dimensions of information that are developed by Chenhall and Morris (1986). Finally, we only focus on measuring firm performance in terms of finance. The success of a tourism firm must also include the non-financial perspectives (for example, customer satisfaction, employee loyalty, etc.) (Kaplan \& Norton, 1996). Therefore, further studies should pay attention to this issue.

\section{References}

Agbejule, A. (2005). The relationship between management accounting systems and perceived environmental uncertainty on managerial performance: a research note. Accounting and Business Research, 35(4), 295-305.

Baines, A., \& Langfield-Smith, K. (2003). Antecedents to management accounting change: A structural equation approach. Accounting, Organizations and Society, 28(7-8), 675-698.

Baker, W. E., \& Sinkula, J. M. (1999). The synergistic effect of market orientation and learning orientation on organizational performance. Journal of the Academy of Marketing Science, 27(4), 411-427. 
Barney, J. (1991). Firm resources and sustained competitive advantage. Journal of Management, 17(1), 99-120.

Bouwens, J., \& Abernethy, M. A. (2000). The consequences of customization on management accounting system design. Accounting, Organizations and Society, 25(3), 221-241.

Buli, B. M. (2017). Entrepreneurial orientation, market orientation and performance of SMEs in the manufacturing industry. Management Research Review, 40(3), 292-309.

Cadez, S., \& Guilding, C. (2008). An exploratory investigation of an integrated contingency model of strategic management accounting. Accounting, Organizations and Society, 33(7-8), 836-863.

Charles, L., Joel, C., \& Samwel, K. C. (2012). Market orientation and firm performance in the manufacturing sector in Kenya. European Journal of Business and Management, 4(10), 20-27.

Chenhall, R. H., \& Morris, D. (1986). The impact of structure, environment, and interdependence on the perceived usefulness of management accounting systems. Accounting Review, 61(1), 16-35.

Chong, V. K. (1996). Management accounting systems, task uncertainty and managerial performance: A research note. Accounting, Organizations and Society, 21(5), 415-421.

Chong, V. K., \& Chong, K. M. (1997). Strategic choices, environmental uncertainty and SBU performance: A note on the intervening role of management accounting systems. Accounting and Business Research, 27(4), 268-276.

Deshpande, R., \& Webster, J. F. E. (1989). Organizational culture and marketing: Defining the research agenda. Journal of Marketing, 53(1), 3-15.

Gillen, J. (2014). Tourism and nation building at the war remnants museum in Ho Chi Minh city, Vietnam. Annals of the Association of American Geographers, 104(6), 1307-1321.

Gruber-Muecke, T., \& Hofer, K. M. (2015). Market orientation, entrepreneurial orientation and performance in emerging markets. International Journal of Emerging Markets, 10(3), 560-571.

Guilding, C., \& McManus, L. (2002). The incidence, perceived merit and antecedents of customer accounting: An exploratory note. Accounting, Organizations and Society, 27(1-2), 45-59.

Gul, F. A., \& Chia, Y. M. (1994). The effects of management accounting systems, perceived environmental uncertainty and decentralization on managerial performance: A test of threeway interaction. Accounting, Organizations and Society, 19(45), 413-426.

Ha, V. D. (2020). Impact of organizational culture on the accounting information system and operational performance of small and medium sized enterprises in Ho Chi Minh City. The Journal of Asian Finance, Economics, and Business, 7(2), 301-308. https://doi.org/10.13106/jafeb.2020.vol7.no2.301

Hair, J. F., Hult, G. T. M., Ringle, C. M., \& Sarstedt, M. (2017). A Primer on Partial Least Squares Structural Equation Modeling (PLS-SEM). Los Angeles, CA: Sage Publications, Inc.
Hampton, M. P., Jeyacheya, J., \& Long, P. H. (2018). Can tourism promote inclusive growth? Supply chains, ownership and employment in Ha Long Bay, Vietnam. The Journal of Development Studies, 54(2), 359-376.

Henri, J.-F. (2006). Management control systems and strategy: A resource-based perspective. Accounting, Organizations and Society, 31(6), 529-558.

Hoque, Z. (2011). The relations among competition, delegation, management accounting systems change and performance: A path model. Advances in Accounting, 27(2), 266-277.

Horngren, C. T. (1995). Management accounting: This century and beyond. Management Accounting Research, 6(3), 281-286.

Hulland, J. (1999). Use of partial least squares (PLS) in strategic management research: A review of four recent studies. Strategic Management Journal, 20(2), 195-204.

Hunt, S. D., \& Morgan, R. M. (1995). The comparative advantage theory of competition. Journal of Marketing, 59(2), 1-15.

Hyvönen, J. (2007). Strategy, performance measurement techniques and information technology of the firm and their links to organizational performance. Management Accounting Research, 18(3), 343-366.

Jaworski, B. J., \& Kohli, A. K. (1993). Market orientation: antecedents and consequences. Journal of Marketing, 57(3), 53-70.

Kaplan, R. S., \& Atkinson, A. A. (1998). Advanced Management Accounting. Upper Saddle River, NJ: Prentice Hall International.

Kaplan, R. S., \& Norton, D. P. (1996). The Balanced Scorecard: Translating strategy into action. Cambridge, MA: Harvard Business Press.

Kohli, A. K., \& Jaworski, B. J. (1990). Market orientation: The construct, research propositions, and managerial implications. Journal of Marketing, 54(2), 1-18.

Li, \& Liu, J. (2014). Dynamic capabilities, environmental dynamism, and competitive advantage: Evidence from China. Journal of Business Research, 67(1), 2793-2799.

Luft, J., \& Shields, M. D. (2003). Mapping management accounting: graphics and guidelines for theory-consistent empirical research. Accounting, Organizations and Society, 28(2-3), 169-249.

Matsuno, K., \& Mentzer, J. T. (2000). The effects of strategy type on the market orientation-performance relationship. Journal of Marketing, 64(4), 1-16.

Mia, L., \& Chenhall, R. H. (1994). The usefulness of management accounting systems, functional differentiation and managerial effectiveness. Accounting, Organizations and Society, 19(1), 1-13.

Mia, L., \& Clarke, B. (1999). Market competition, management accounting systems and business unit performance. Management Accounting Research, 10(2), 137-158.

Naranjo-Gil, D., \& Hartmann, F. (2007). Management accounting systems, top management team heterogeneity and strategic change. Accounting, Organizations and Society, 32(7-8), 735-756. 
Narver, J. C., \& Slater, S. F. (1990). The effect of a market orientation on business profitability. Journal of Marketing, 54(4), 20-35.

Nguyen, H. Q., \& Le, O. T. T. (2020). Factors Affecting the Intention to Apply Management Accounting in Enterprises in Vietnam. Journal of Asian Finance, Economics, and Business, 7(6), 95-107. https://doi.org/10.13106/jafeb.2020.vol7.no6.095

Nguyen, P. N. (2018). Performance implication of market orientation and use of management accounting systems: The moderating role of accountants' participation in strategic decision making. Journal of Asian Business and Economic Studies, 25(1), 33-49.

Nguyen, P. N., \& Doan, N. Q. (2016). Impact of market orientation and competitive pressure to the level of using management accounting information to improve firm performance in Vietnamese enterprises. Journal of Economics and Development, 27(11), 98-123.

Nguyen, T. T., Mia, L., Winata, L., \& Chong, V. K. (2017). Effect of transformational-leadership style and management control system on managerial performance. Journal of Business Research, 70, 202-213.

O'Cass, A., \& Ngo, L. V. (2007). Market orientation versus innovative culture: Two routes to superior brand performance. European Journal of Marketing, 41(7-8), 868-887.

Pham, D. H., Dao, T. H., \& Bui, T. D. (2020). The Impact of Contingency Factors on Management Accounting Practices in Vietnam. Journal of Asian Finance, Economics and Business, 7(8), 77-85. https://doi.org/10.13106/jafeb.2020.vol7.no8.077

Phornlaphatrachakorn, K., \& Na-Kalasindhu, K. (2020). Strategic Management Accounting and Firm Performance: Evidence from Finance Businesses in Thailand. Journal of Asian Finance, Economics and Business, 7(8), 309-321. https://doi. org/10.13106/jafeb.2020.vol7.no8.309

Shahzad, S. J. H., Shahbaz, M., Ferrer, R., \& Kumar, R. R. (2017). Tourism-led growth hypothesis in the top ten tourist destinations: New evidence using the quantile-on-quantile approach. Tourism Management, 60, 223-232.

Slater, S. F., \& Narver, J. C. (1994). Does competitive environment moderate the market orientation-performance relationship? Journal of Marketing, 58(1), 46-55.

Soobaroyen, T., \& Poorundersing, B. (2008). The effectiveness of management accounting systems: Evidence from functional managers in a developing country. Managerial Auditing Journal, 23(2), 187-219.

Wang, C.-H., Chen, K.-Y., \& Chen, S.-C. (2012). Total quality management, market orientation and hotel performance: The moderating effects of external environmental factors. International Journal of Hospitality Management, 31(1), 119-129.

WTTC. (2020). Travel \& Tourism: Global Economic Impact \& Trends 2020. London, UK: WTTC.

Wu, H., Chen, J., \& Jiao, H. (2016). Dynamic capabilities as a mediator linking international diversification and innovation performance of firms in an emerging economy. Journal of Business Research, 69(8), 2678-2686.

Yuliansyah, Y., Khan, A. A., \& Fadhilah, A. (2019). Strategic performance measurement system, firm capabilities andcustomer-focused strategy. Pacific Accounting Review, 31(2), 288-307.

Zhou, K. Z., Brown, J. R., \& Dev, C. S. (2009). Market orientation, competitive advantage, and performance: A demand-based perspective. Journal of Business Research, 62(11), 1063-1070.

Zhou, K. Z., Li, J. J., Zhou, N., \& Su, C. (2008). Market orientation, job satisfaction, product quality, and firm performance: evidence from China. Strategic Management Journal, 29(9), 985-1000. 
Appendix A: Factor loading and t-value of the constructs

\begin{tabular}{|c|c|c|c|}
\hline Code & Constructs and items & $\begin{array}{l}\text { Factor } \\
\text { loading }\end{array}$ & t-value \\
\hline \multicolumn{4}{|c|}{ Management accounting information usage } \\
\hline MAI1 & Information that relates to possible future events. & 0.869 & 40.577 \\
\hline MAI2 & Non-financial information that relates to production and market. & 0.768 & 16.404 \\
\hline MAI3 & $\begin{array}{l}\text { Other non-financial information, such as customers' references, actions of competitors, } \\
\text { etc. }\end{array}$ & 0.785 & 20.803 \\
\hline MAI4 & $\begin{array}{l}\text { Information on broad factors external to your organization, such as economic conditions, } \\
\text { technological development, etc. }\end{array}$ & 0.852 & 32.026 \\
\hline \multicolumn{4}{|c|}{ Information generation } \\
\hline IG1 & We are fast to detect changes in our customers' product preference. & 0.848 & 30.923 \\
\hline IG2 & $\begin{array}{l}\text { We are fast to detect fundamental shifts in our industry (e.g., competition, technology, } \\
\text { regulation). }\end{array}$ & 0.828 & 26.314 \\
\hline IG3 & $\begin{array}{l}\text { We periodically review the likely effect of changes in our business environment (e.g., } \\
\text { regulation) on customers. }\end{array}$ & 0.751 & 17.619 \\
\hline \multicolumn{4}{|c|}{ Information dissemination } \\
\hline ID1 & $\begin{array}{l}\text { When something important happens to a major customer or market, the whole } \\
\text { organization knows about it in a short period. }\end{array}$ & 0.824 & 17.154 \\
\hline ID2 & $\begin{array}{l}\text { Customer suggestions and comments are disseminated at all levels in the organization } \\
\text { on a regular basis. }\end{array}$ & 0.873 & 24.862 \\
\hline \multicolumn{4}{|c|}{ Responsiveness } \\
\hline RE1 & We pay close attention to the changes in our customers' needs. & 0.874 & 36.445 \\
\hline RE2 & $\begin{array}{l}\text { If a major competitor launched a campaign to our customers, we implement a response } \\
\text { immediately. }\end{array}$ & 0.862 & 28.896 \\
\hline RE3 & We can effectively implement a marketing plan in a timely fashion. & 0.793 & 21.551 \\
\hline \multicolumn{4}{|c|}{ Firm performance } \\
\hline FP1 & Sales growth rate & 0.670 & 10.176 \\
\hline FP2 & Market share & 0.730 & 15.281 \\
\hline FP3 & Operating profit & 0.729 & 14.870 \\
\hline FP4 & Return on investment & 0.771 & 18.825 \\
\hline FP5 & Cash flow from operation & 0.504 & 5.654 \\
\hline
\end{tabular}

